\section{Intersections}

Canadian Journal of Music

Revue canadienne de musique
Intersections CANADIAN JOURAL OR MUSIC

\title{
Anhalt's Oppenheimer: The History of a Never-Finished Major Work
}

\section{John Beckwith}

Volume 33, numéro 2, 2013

Musical Perspectives, People, and Places: Essays in Honour of Carl Morey

URI : https://id.erudit.org/iderudit/1032697ar

DOI : https://doi.org/10.7202/1032697ar

Aller au sommaire du numéro

\section{Éditeur(s)}

Canadian University Music Society / Société de musique des universités canadiennes

\section{ISSN}

1911-0146 (imprimé)

1918-512X (numérique)

Découvrir la revue

Citer cet article

Beckwith, J. (2013). Anhalt's Oppenheimer: The History of a Never-Finished Major Work. Intersections, 33(2), 101-114. https://doi.org/10.7202/1032697ar

\section{Résumé de l'article}

Une version de travail du livret d'opéra pour l'opéra-fantasie Oppenheimer d'Istvan Anhalt (1919-2012) est conservée ainsi que 1100 pages d'esquisses musicales (Bibliothèque et Archives Canada, Fonds Anhalt, MUS 164). Le compositeur a travaillé principalement sur cette oeuvre de mi-1987 à fin 1991, parfois avec la collaboration du dramaturge John Murrell. De longues négociations avec la Canadian Opera Company ont finalement mené à un échec et le projet a été abandonné. Sur la base des recherches de Peter Laki et des documents d'archives (en particulier le journal de projet du compositeur, jusqu'à maintenant inaccessible), cet article retrace le développement compositionnel d'Oppenheimer ainsi que les négociations avec la $\mathrm{COC}$, en comparaison avec l'opéra de John Adams et Peter Sellars, Doctor Atomic (2005), les deux opéras traitant du rôle du physicien J. Robert Oppenheimer dans le développement de la bombe atomique en 1945. L'examen des esquisses amène également à considérer les affinités entre elles et avec d'autres oeuvres d'Anhalt de la même période.
Copyright (c) Canadian University Music Society / Société de musique des universités canadiennes, 2013
Ce document est protégé par la loi sur le droit d'auteur. L'utilisation des services d'Érudit (y compris la reproduction) est assujettie à sa politique d'utilisation que vous pouvez consulter en ligne.

https://apropos.erudit.org/fr/usagers/politique-dutilisation/ 


\title{
ANHALT'S OPPENHEIMER: THE HISTORY OF A NEVER-FINISHED MAJOR WORK ${ }^{1}$
}

\author{
John Beckwith
}

In a letter of April 1988, the composer Istvan Anhalt mentioned "the project about which I spoke to you ... ca. 6-8 months ago."2 This places the germ of the project in mid-to-late 1987. Four days later, in another letter, Anhalt said he had been "reading into at least 3 topics" suitable for a major musico-dramatic work. ${ }^{3}$ In neither letter was the topic identified. In 1975 Anhalt had composed La Tourangelle, a "musical tableau" about the Ursuline nun and Quebec pioneer Marie de l'Incarnation, and followed it in 1983 with Winthrop, an "historical pageant" about the first governor of Massachusetts, John Winthrop. Anhalt said later that after having produced a work about a French-born Catholic and another about an English-born Protestant, "I began to think ... I should consider adding a third work, one based on the story of a Jewish figure" (Anhalt 2001, 169). Two of the potential Jewish protagonists about whom he had been reading can be identified - the founder of psychoanalysis, Sigmund Freud, and the nuclear physicist J. Robert Oppenheimer-while the third evidently remains a secret.

Later in 1988, in Toledo, Spain, Istvan and Beate Anhalt visited the site of the sixteenth-century Inquisition trial of Elvira del Campo, which struck Anhalt as an analogy to Oppenheimer's 1954 security hearing before the U.S. Atomic Energy Commission. Making a definite choice of Oppenheimer, he began a journal or log of the project. Most events and dates to follow are taken from this source, referred to as the "Oppenheimer diary" (OD). The journal, handwritten, grew to two volumes and was eventually deposited in the Anhalt Fonds at Library and Archives Canada with the restriction that it should not be opened until after the composer's death. Anhalt died aged ninety-two in February 2012, and the seal was broken in September of that year; I was the first person to read it. The composer noted in the first entry (OD 8 November 1988; see figure 1) that Oppenheimer's son Peter had given him permission to pursue such a venture.

He steeped himself in the transcript of the commission hearing, and towards the end of 1988 went to New York to interview the physicist Robert Serber, Oppenheimer's friend and former student. By 4 January 1989, Anhalt was

1 This article is based on a paper delivered at the conference of the Canadian University Music Society, University of Victoria, 7 June 2013.

2 Anhalt to David Jaeger, 14 April 1988.

3 Anhalt to John Beckwith, 18 April 1988, 10.D.10, John Beckwith papers, Faculty of Music Library, University of Toronto. 
102

Intersections

Nov. 8,1988

Yesterday Peter Oppenheimer's response (dated Oct .24) arrived. I an very glad, that Re, cautiously agrees to kep with a possible' (?.) opera about his fatter am contemplating to write. While this is not a 'decisive event, itgreaty helps in a positive way.' Slowly $10 \mathrm{am}$ mooing tourer os gathering up the necessary resolve (courage) to agile (within' that I shall nobertake dow g it. Yet much essential insight is missing. I see 0 . clearly enough as a public figure, as a part of history (political and cultural ste.) but I do not see him as a private' parson. I wish loved Know what he wis like when tho bust guest $b f t$ ' after the party; Ww hen he got home after a bomisung committee fist. how he talked to his wife; what that marmige was like; there and other in werd-dere stud questions bey for some answer. I coned invent) him, hut this is not justified as long as eye-witnens (Peter, colleypus fines, ate. enemies) are still around rive possibly wining to speak to we about $O$ 's private side!

Figure 1. First entry by Anhalt in his Oppenheimer diary 
ready to read to David Jaeger and Karen Kieser, of the CBC, a draft libretto for a three-act opera tentatively entitled Oppenheimer. They suggested he should approach Brian Dickie, newly installed as general director of the Canadian Opera Company. The company was anticipating approval for a new home at Wellesley and Bay Streets in Toronto, the opulent ballet-opera house designed by Moshe Safdie, and they expected to commission a new opera for its opening.

The log gives a dramatic account of the story as it unfolded. In June 1989 Anhalt sends a second libretto draft to Richard Bradshaw, newly appointed by Dickie as the COC's music director, and receives an enthusiastic response. Bradshaw mentions Peter Sellars as a possible stage director. Dickie and Bradshaw encourage Anhalt to work with a professional librettist, so in the ensuing months he approaches in turn Mavor Moore, James Reaney, and Lister Sinclair. The first two express interest but are unable to accept collaboration; from Sinclair there is no response. ${ }^{4}$ While the search for a collaborator continues, Anhalt continues to elaborate his draft libretto: a seventh version incorporates his further researches in libraries in Washington and New York. ${ }^{5}$ In June 1990, Fred Euringer of the Queen's University Drama Department suggests the playwright and opera buff John Murrell. Anhalt talks on the phone with Murrell, who becomes immediately interested, and on 26 July the two of them confer in Kingston for ten hours and agree to collaborate. Murrell visits again, 3-5 September, with a new outline for the opera. Anhalt writes, "Our working relationship cannot be better ... We will be talking at the level of utmost candidness/openness" (OD 8 September, 1990).

The COC reads the new libretto-outline, and Murrell reports that Brian Dickie is "extremely excited about the collaboration ... It looks as though we now have the makings of a very successful piece indeed." Dickie has suggested Robin Phillips as a possible stage director, and after reading the outline Phillips is "very interested." On 15 October the three-Anhalt, Murrell, and Phillipsmeet in a Toronto restaurant to discuss the project, ending with a three-way handshake confirming their commitment.

Storm clouds appear on the horizon. Bradshaw is miffed that Phillips is now considered part of the "team"; since this was Dickie's suggestion, it should have been his decision. The company awaits word about public support for the ballet-opera house. In November the Ontario government withdraws its offer of support for the design, and fund-raising comes to a halt. Undeterred, Murrell remains committed to the Oppenheimer project, and as for Anhalt he has begun sketching the music, noting in his log, "Material is accumulating ... a page for Robert, ideas for Jean, Kitty, notes on lined paper ... as if [I were] turning the dials of a listening device" (OD 31 October 1990). On 23 November in a phone conversation Bradshaw says the company is prepared to commission the new opera, and a letter to this effect arrives on the 3oth, specifying a

4 It was Moore who suggested Lister Sinclair. Reaney admired the idea but felt he would not be the right person to write the libretto. He asked whether Anhalt would consider making an opera out of the first play in his dramatic trilogy The Donnellys (OD 30 March 1990).

5 Draft 7 is dated 6 July 1990.

6 Dickie to Murrell (OD 30 March 1990). 
production in the summer of 1995 at the Elgin Theatre or in the new house if plans for it are revived?

While Murrell continues to develop the libretto, Anhalt visits Los Alamos, New Mexico, and talks with staff members about their memories of Oppenheimer and the wartime laboratory. Oppenheimer's colleague and rival physicist Edward Teller happens to be making a short visit, and Anhalt is able to interview him. He shares his findings with Murrell on his return, 16-17 March, and records their meeting in positive terms (OD 18 March 1991).

Uneasy at having as yet no firm agreement with the COC, Anhalt signs with Murrell's New York agent, Susan Schulman (OD 17 April 1991). ${ }^{8}$ Though frustrated by Dickie's evident inaccessibility and the long delay, Anhalt continues to produce musical ideas. The agreement, arriving in June, makes demands that he considers excessive. The company wants to receive sample scenes for workshopping prior to making definite production plans, and it is unclear who will take responsibility for preparing the vocal score, full score, and instrumental parts-the composer or the company. Not satisfied with having Schulman deal with these issues, Anhalt consults his lawyer. In August, talks with Murrell and with the company's music administrator, Janet Stubbs, are reassuring. Compromises emerge: the COC will pay for the preparation of the vocal score; Bradshaw asks Anhalt to concede on the workshopping. But when the actual contract arrives on 28 September, Anhalt is dismayed both by the implied curtailment of his creative autonomy- "interfering with my own personal rhythm," as he later put it (OD 10 October 1991) - and by the suggested date for completion, giving him a shorter time than he had planned. After several exchanges in which Bradshaw calls Anhalt "a difficult person" and accuses him of prolonging their discussions needlessly, Dickie writes (OD 9 October 1991) to inform Anhalt's lawyer that the COC is calling off negotiations.

The foregoing summarizes the account in Anhalt's log. In a recent communication, John Murrell recalled a decisive moment in the discussions. Exasperated at not hearing from Brian Dickie, Anhalt acquired the restricted phone number where Dickie was vacationing in Florida and called him there, and Dickie ended their tense talk by abruptly hanging up. ${ }^{9}$ Murrell regards this as the "fatal phone call" that killed negotiations. Anhalt may have realized that it was a tactical blunder to confront Dickie in such a way. He had no experience of working through an agent (unlike their U.S. confreres, few Canadian composers have agents). But to pose an explanation for the blunder is not to excuse it. Having hired Schulman to act on his behalf, the proper thing would have been to let her handle matters.

7 In the discussion of terms, Murrell referred the COC to his agent, while Anhalt asked the company to make him an offer. In Bradshaw's view, it would be based on Michael Tippett's fee for his Glyndebourne / Houston Opera commission, New Year (OD 26 October 1990).

8 "It appears that we have entered the period of horse trading" (OD 3 May 1991). Schulman requested \$20,000-\$25,000 for Murrell as librettist, and thought Anhalt should receive "several times" that amount for the music (OD 19 December 1990).

9 E-mail, John Murrell to John Beckwith, 4 May 2013. 
As a postscript to the negotiations, Susan Schulman told Anhalt that the COC had approached Murrell for a libretto on the Oppenheimer theme to be produced in collaboration with another composer (not named). John Murrell has confirmed that he declined this offer, on the grounds that a large amount of the previous research was done by Anhalt. ${ }^{10}$

For several important previous works-Cento, Foci, La Tourangelle, Winthrop, and Thisness-Anhalt either compiled the texts from sources he had researched, or wrote original texts. His draft libretto for Oppenheimer is full of ideas and allusions regarding the physicist's extraordinary career and his stature as the "father of the atomic bomb." It contains three acts, each divided into nine short scenes. The action constantly shifts in time and locale. Rather than proceeding chronologically, successive scenes take place in the late 1930s and early 1940 os in Berkeley, California; or in the early 1940 os in Los Alamos, New Mexico, at the laboratories or Oppenheimer's home; in the Oval Office of the White House, Washington, under three presidents, Truman, Eisenhower, and Johnson; or at the 1954 hearings of the Atomic Energy Commission, also in Washington; or Oppenheimer's postwar office at Princeton.

Oppenheimer has been called a "Promethean" figure (notably in the title of Bird and Sherwin 2005), after Prometheus, who in Greek mythology stole fire from the gods and brought it to humanity-and was punished for doing so. Anhalt incorporates this analogy in his libretto (act 2, scene 5). His draft includes three further analogies. His subtitle for Oppenheimer is "an operafantasy," and in the libretto's preface he writes, "These ['analogy' scenes] point to mythical and/or historical antecedents or parallels. The purpose in these sections is to lift protagonists from the level of the 'quasi-real' to the level of the archetypal, thereby endowing them with enhanced meaning" (Anhalt 1990). In act 3, a "dream scene" forms a structural counterpart to the "analogies" of the other acts, again interweaving "quasi-real" and "archetypal" elements. Here Oppenheimer and his son become parallels to Daedalus and Icarus-another borrowing from Greek mythology.

In the first analogy of act 1, Oppenheimer is linked to Laocoön, the Trojan priest who warned his fellow citizens not to accept the wooden horse offered by their Greek enemies ("beware of Greeks bearing gifts"); in punishment the gods sent a pair of sea serpents to strangle him and his two sons. The second analogy depicts Rabbi Judah Loew and the Golem of Prague, a legendary creature made of clay and brought to life through spiritual incantations in order to protect the Jewish community from persecution, who becomes destructive when out of the rabbi's control. These reminders, one from classical mythology and the other from a sixteenth-century European legend, dramatize the warnings of Oppenheimer and other scientists about the potential uncontrollability of the new nuclear powers, and suggest a mirror to Oppenheimer's security hearing. Through his leftist sympathies and associations with Communist Party members (his wife Kitty, his mistress Jean Tatlock, and his friend

10 Ibid. 
Haakon Chevalier, a professor of French at Berkeley), the commission judged him to be a security risk and punished him by revoking his clearance.

In act 2, a third analogy transforms Jean Tatlock into the sixteenth-century Spanish heroine Elvira del Campo. A descendant of a converso family, Jews who had converted to Christianity, she was tried and horribly tortured by the Inquisition when suspected of secretly practising Judaism. In 1944, Oppenheimer was deeply affected on hearing that Tatlock had committed suicide by drowning. The fourth of the analogies is the Prometheus myth, of obvious relevance to the Trinity explosion of July 1945, the climactic finale to act 2.

The most definitive libretto draft (Anhalt 1990) lists the forces required for this ambitious work: fourteen principal solo singers, most of whom take more than one role; ten silent roles; a chamber chorus of twelve to sixteen voices; twelve dancers; plus an orchestra of, Anhalt estimates, "thirty to forty" players. ${ }^{11}$ Besides J. Robert Oppenheimer, Kitty Oppenheimer, and Jean Tatlock, characters include physicists at Los Alamos (Edward Teller, Robert Fynman, Hans Bethe, Robert Serber, and others); Brigadier-General Leslie R. Groves, military liaison to the bomb project; L. L. Strauss, chair, and several members of the Atomic Energy Commission; Haakon Chevalier; Oppenheimer's secretary; his son Peter; and, in an epilogue, a Soviet figure from the 1980s, Andrei Sakarov. (As a scientist suspected of disloyalty and exiled by his political masters, Sakarov struck Anhalt as a contemporary analogy to Oppenheimer.) The same singers portray both the "quasi-real" characters and their "archetypal" equivalents. In addition, the list of participants indicates Anhalt envisioned using puppets for some passages in the "analogies." The work's scope and dramatic power are impressive, but characters and scenes would no doubt have been cut down as it proceeded towards practical production. In fact, Anhalt said in 2008 that "had he been able to proceed he would have reduced the material [of the opera] substantially." ${ }^{2}$

John Murrell's "Preliminary Structural Outline" of his version bears the title "Oppenheimer and the Others." Evidently aiming for a more practical scale, it calls for nine main singers and unfolds in two acts of altogether five scenes. Though incorporating much of Anhalt's research and covering Oppenheimer's career almost as extensively as Anhalt had imagined, it employs fewer "analogies" and places greater emphasis on the relationship of Oppenheimer with Jean Tatlock. ${ }^{13}$

Oppenheimer's brilliance and the exceptional challenges, personal and professional, that he faced make him a rich subject for operatic treatment. The experiments that led to the test explosion had tremendous implications. After the Hiroshima and Nagasaki bombings, Oppenheimer told President Harry Truman that he felt he had "blood on his hands." His political downfall in the commission hearing broke his spirit, and the presentation a decade

11 The orchestra is not mentioned in this libretto list. The estimate given here derives from an early letter to David Jaeger (24 October 1988, Jaeger collection), which also refers to a possible "electronic layer," an element evidently dropped in later stages.

12 Anhalt, phone conversation with Peter Laki, 25 May 2008, reported in Laki 2009, 4.

13 No further versions of the Murrell libretto have been preserved. 
later by President Lyndon B. Johnson of the Fermi Award, a kind of pardon, came too late to effectively restore it. Oppenheimer died four years later, aged sixty-three.

In 2005 the focus of the story, the creation of the atomic bomb, formed the basis of the opera Doctor Atomic, with music by John Adams and libretto by Peter Sellars. In 2009, the musicologist Peter Laki made a detailed comparison of this work with Anhalt's projected opera (Laki 2009). Although J. Robert Oppenheimer is the central figure in both, their treatments are quite different. The libretto envisioned by Anhalt and Murrell covers thirty years of Oppenheimer's life, while Sellars's concentrates on the crucial events of 1945 . The Anhalt libretto is largely made up of original text, while Sellars uses only quotations from correspondence, official documents, and literary sources. The sonnet by John Donne beginning "Batter my heart, three-person'd God," a favourite of Oppenheimer's from which he chose the name "Trinity" for the first test explosion, forms a long duet sequence for the Oppenheimers at the end of act 1 of Doctor Atomic; coincidentally Anhalt quotes it in his act 2, scene 3. Doctor Atomic has achieved international success. Laki ends his examination of Anhalt's draft script by noting that "some of the ideas that were brought to fruition by the American composer had begun to take shape, several years earlier, north of the border in Kingston, Ontario." In a recent communication John Adams said he was "not aware of Anhalt's Oppenheimer project."14

Contrary to references about Oppenheimer in the Anhalt literature, ${ }^{15}$ the musical sketches for the proposed Anhalt/Murrell opera are extensive, filling four boxes in the Anhalt Fonds at Library and Archives Canada, for a total of 1,176 score-sized pages. After finishing the seventh version of his draft libretto, Anhalt evidently worked on ideas for the music for six months-fall 1990 to early spring 1991. Reviewing the contents of box 1 as a substantial sample, I found the vocal lines have no text and no indication of the particular scenes they are designed for, while the instrumental lines, on two to six staves, only rarely bear specific allocations, though pages are carefully numbered. There are indications of serial processes the composer intended to use: six "core characters" are identified with six intervals, a semitone for Groves, a whole tone for Frank Oppenheimer (the physicist's brother, a suggested added character), a minor third for Kitty, a major third for Oppenheimer, a perfect fourth for Jean, and a tritone for Teller. A passage labelled "the 'thinking' Robert" is based on "Row XVIII," a twelve-tone set containing six semitones (27; see example 1). Many pages include serial numberings-6I, $11 \mathrm{R}$, and so on-indicating transpositions, inversions, and retrogrades of a set (e.g., 37; see example 2). On one page, instrumental motifs are noted without metre or tempo, based on a hexachord and its inversion, and there are single-line presentations of a tetrachord, developed in syncopated rhythm and repeated with a reduction of

14 Edward C. Yim, agent for John Adams, to John Beckwith, 11 May 2013.

15 For example, Chiasson-Taylor 2011, 200: "Le matériel d'Oppenheimer se limite à quelques esquisses." 


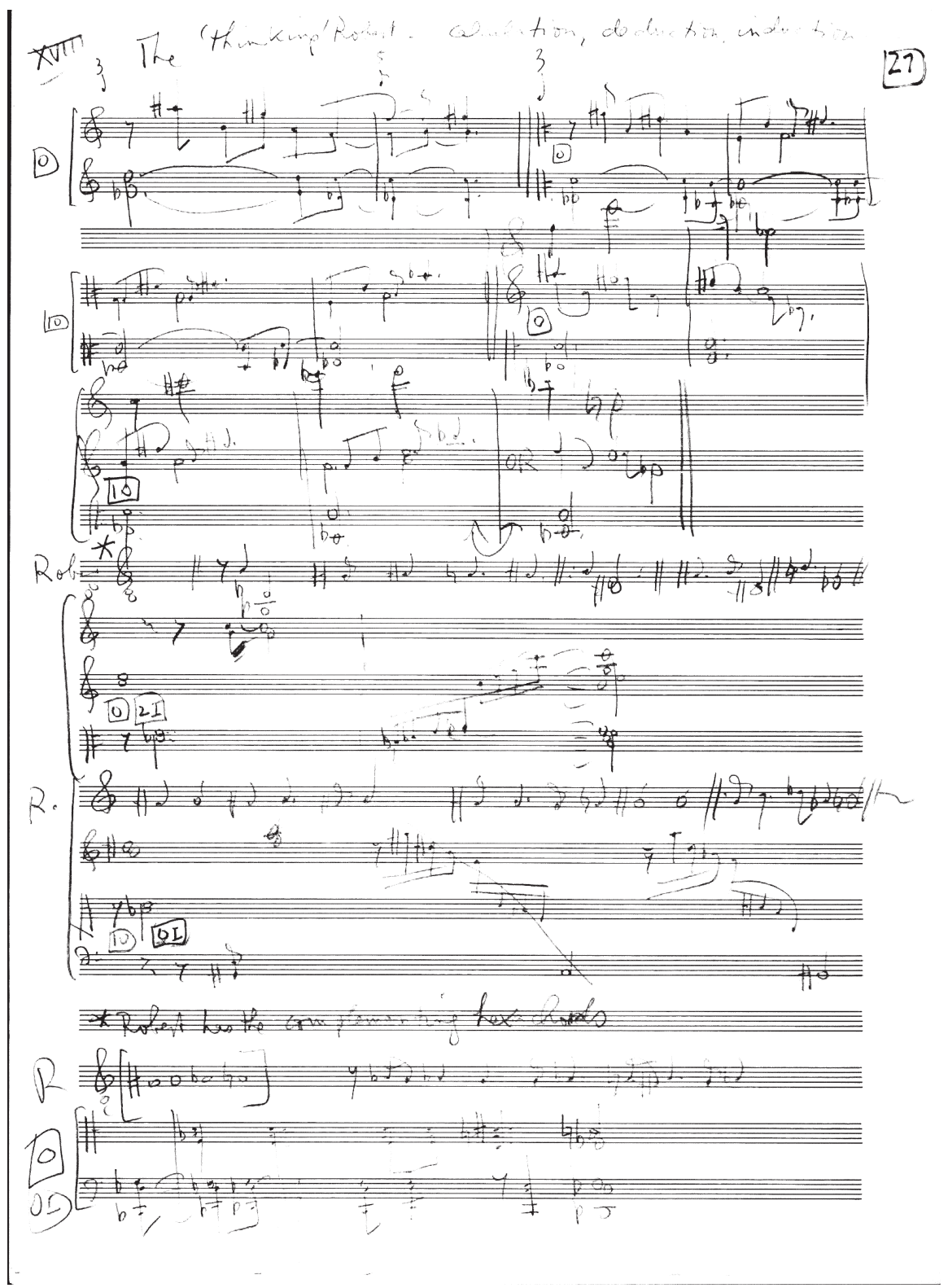

Example 1. Row XVIII ("the thinking Robert") from Anhalt's Oppenheimer sketches (file D1.91, box 60, MUS 164, Libraries and Archives Canada) 


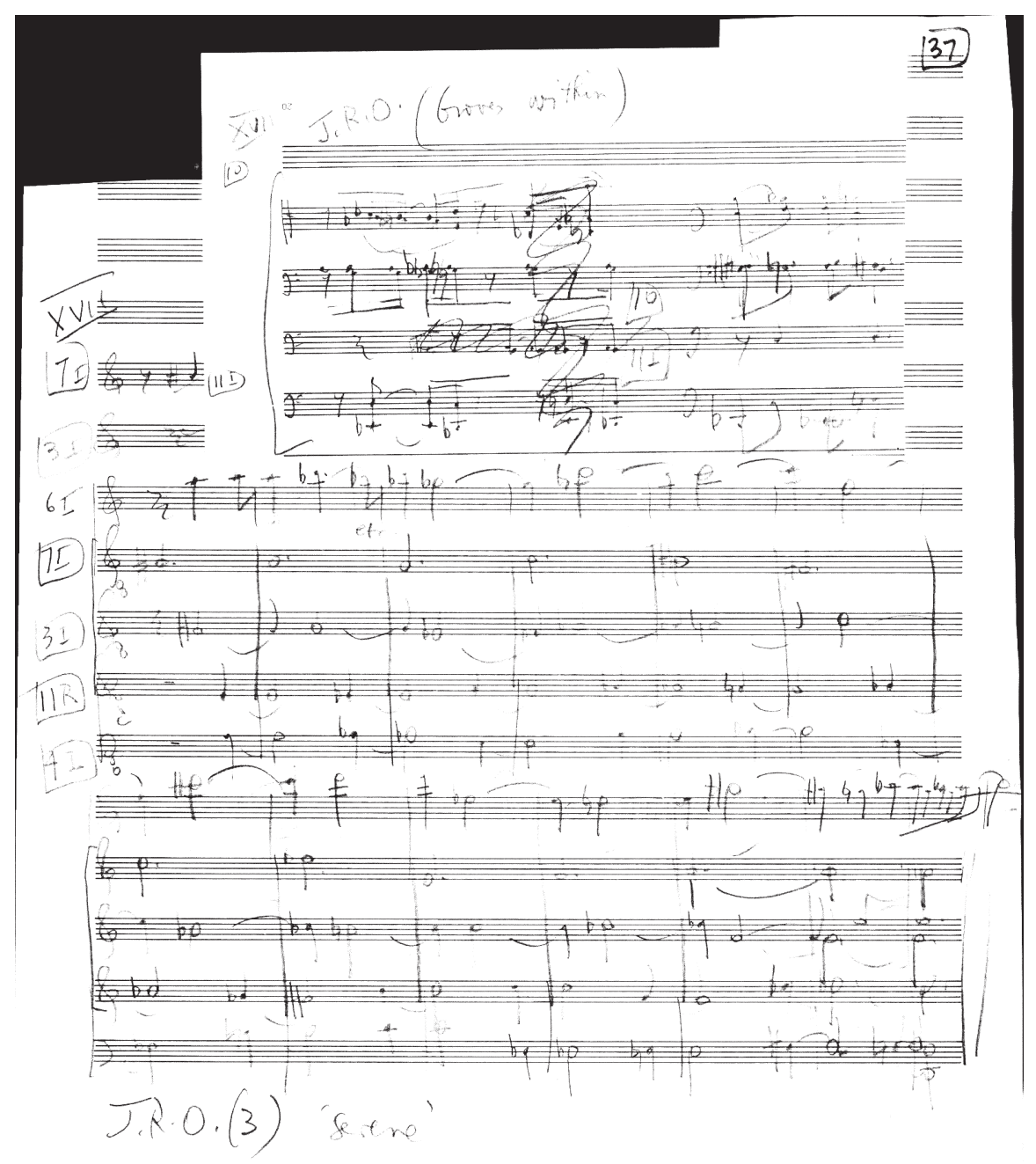

Example 2. Page indicating serial numbers, from Anhalt's Oppenheimer sketches (file D1.91, box 60, MUS 164, Libraries and Archives Canada) 

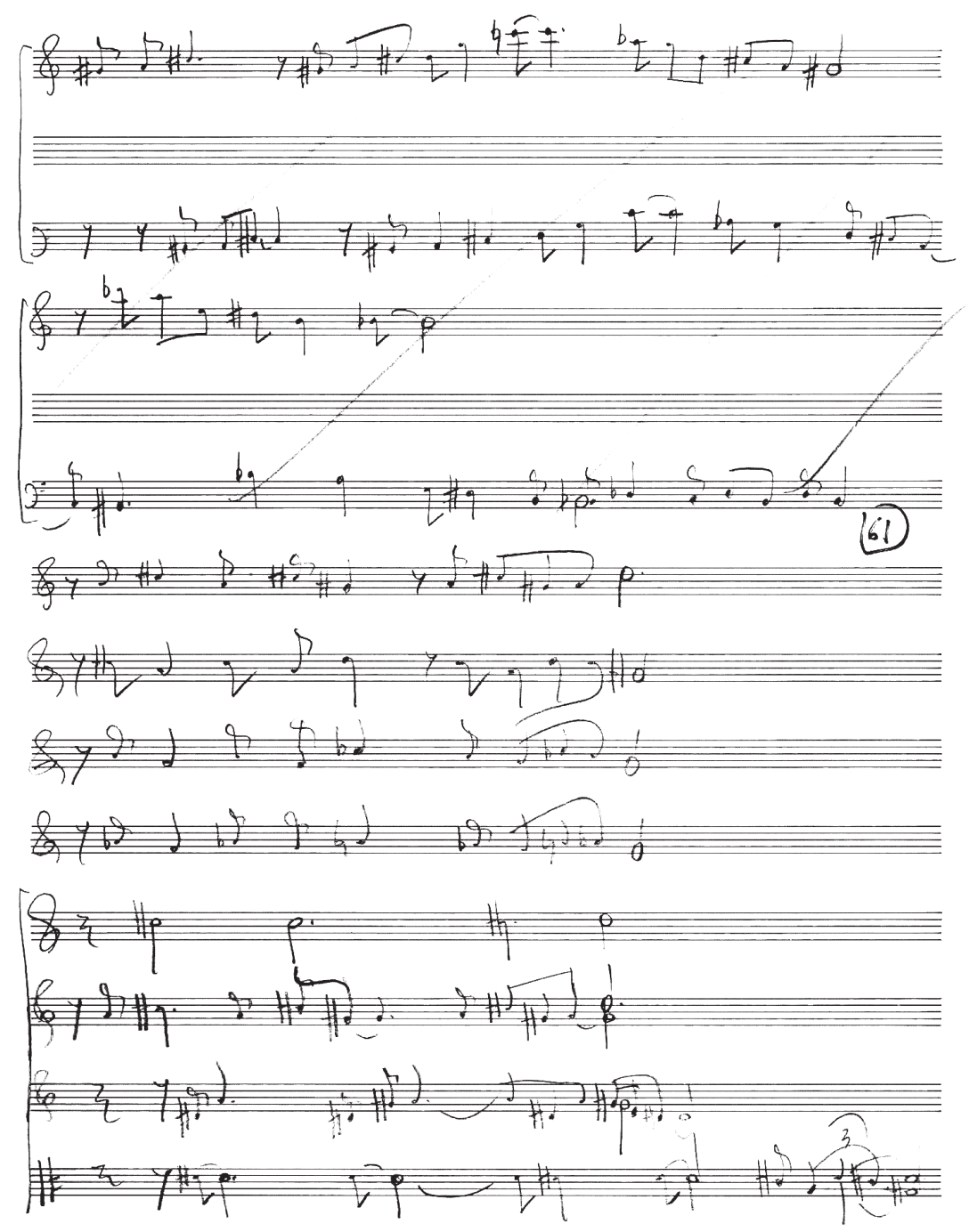

Example 3. Various treatments of instrumental ideas from Anhalt's Oppenheimer sketches (file D1.91, box 60, MUS 164, Libraries and Archives Canada) 
each interval by a semitone, followed by a presentation on four staves-again, without assignments to particular instruments (61; see example 3).

Further ideas on four staves are headed "Accompaniment to a part of J.R.O.'s 'Eagle' aria??" (64) and on another page a new set is labelled "Row X (Eagle row)" (86). The reference can be linked perhaps to solo lines of Oppenheimer in the libretto. On two pages a musical quotation is identified: "Fragments/paraphrases from the 'Internationale,' suggesting echoes from J.R.O.'s communist involvement" (96). A sequence of overlapping sixteenth-note gestures based on $\mathrm{P}$ and I forms of a six-note set, in four-to-five instrumental parts, is meant to depict Oppenheimer's "lightning fast mind," and the composer's memo adds "(This might be computer-synthesized, transposed, overlayed [sic], etc.") (7). An insert shows two canonic voice parts labelled "Kitty" and "Robert," with two accompanying slower parts, mainly in semitones, with the note, "This canon is dedicated to Gene and George Rochberg on their 5oth wedding anniversary" (11). Anhalt made a copy of the canon with an added text unrelated to Oppenheimer and sent it to the Rochbergs (see Gillmor 2007, 255-57).

That his projected score for Oppenheimer promises some use of serial procedures should not cause surprise, given the work habits of his long career. The notion that serialism dominated the technical thinking of all composers during the mid-twentieth century and of no composers after that is a favourite myth of the non-specialist media. Commenting on an article of 2008 that debunked this notion (Straus 2008, 208-09), Anhalt wrote concerning his own work, "I call this framework (as it may apply in my case) sundry symmetrical constructs, of which 12-tone constructs form a sub-class."16

Oppenheimer relates to the works by Anhalt that immediately preceded itthe "duo-drama" Thisness (1985) and the two orchestral pieces, Simulacrum and SparkskrapS (both 1987) -in that its "fantasy" passages draw on his extensive readings in Jewish history. The work that immediately followed-Traces (Tikkun) (1992-93) - is similarly dependent on those literary stimuli. It is a "pluri-drama" for solo baritone and orchestra, based on his own experiences towards the end of the Second World War, as a member of a Jewish labour force under the Hungarian army, an escapee, and a witness of the Budapest siege of 1944-45. That some of the vast Oppenheimer sketch material ended up in Traces seems highly probable, but is not so far verified.

Why did the Oppenheimer project collapse? It would have been Anhalt's first opera. Though his earlier dramatic pieces were later called operas, they do not include dialogue between personages (with the possible exception of the trial in Winthrop), nor do they envisage stage action. Anhalt once called them "mind-operas" (Smith 2006, 172). But with Oppenheimer he entered unfamiliar territory and was uneasy about the COC's "interference" in the creative process. Murrell too was tackling his first opera libretto, though he was a recognized dramatist and was later to write several libretti.

16 Anhalt to John Beckwith, 17 September 2008, 10.D.10, John Beckwith papers, Faculty of Music Library, University of Toronto 
If Anhalt appears as a stubborn negotiator, the Canadian Opera Company is hardly blameless in this sad story. Both Brian Dickie and Richard Bradshaw were new to their jobs in Toronto, and in previous positions neither had dealt with composers and commissions. In 1992 the COC mounted at the Elgin Theatre a new opera by Harry Somers and Rod Anderson, Mario and the Magician, after Thomas Mann-a COC commission initiated under Dickie's predecessor, Lotfi Mansouri. Anhalt records in his Oppenheimer diary a consultation with Somers; he felt encouraged when the latter said he was comfortable working with the company (OD 11 September 1991). In 1999 Richard Bradshaw (now general director) commissioned and produced The Golden Ass by Randolph Peters and Robertson Davies. The lavish and costly production had a "mixed" critical and audience reception and was not taken up by other companies. Another prospective main-stage commission, The Scarlet Princess, by Alexina Louie and David Henry Hwang, went through at least three partial or complete workshops and after long delay was given a single concert performance in 2002. At the time of writing, seven years after inaugurating its new home, the Four Seasons Centre, the Canadian Opera Company has yet to present a Canadian opera on its stage. ${ }^{17}$

Though I call Oppenheimer a "never-finished" work, "abandoned" might be a more accurate term. Putting the experience behind him, Istvan Anhalt continued in a vigorous compositional career well into his late eighties, producing Traces, Millennial Mall, and five major orchestral works, among them the much-praised Tents of Abraham. What remains of Oppenheimer could hardly be resurrected into a performable opera. Various writings, including some by the composer himself, describe the libretto as "a three-act play," ${ }^{8}$ but its most finished version assigns vocal types to the leading characters and there are passages for a chorus - which suggests that substantial reshaping would be needed before the script of a spoken drama could emerge. Meanwhile, the libretto and its evolution form a vivid reminder of a substantial (if aborted) venture in Anhalt's creative life, and the musical results are worthy of investigation beyond the scope of this article.

\section{REFERENCES}

Anhalt, Istvan. 2001. "An Operatic Triptych in Multiple Texts," in Istvan Anhalt: Pathways and Memory, ed. Robin Elliott and Gordon E. Smith, 36999. Montreal and Kingston: McGill-Queen's University Press.

.1988-91. Oppenheimer diary, file E.17, box 32, Istvan Anhalt Fonds, MUS 164, Library and Archives Canada, Ottawa.

-1990. Oppenheimer, draft libretto, version 7, file D1.9o, box 6o, MUS 164, Istvan Anhalt Fonds, Library and Archives Canada, Ottawa.

17 In November 2013 the company announced a commission for an opera by Rufus Wainwright, composer, and Daniel MacIvor, librettist. The work was under discussion for three years and is to be performed in the 2018-19 season. See "Notebook" and "New Works," Opera Canada 55 (Winter 2013-14): 4, 6 respectively.

18 Anhalt to John Beckwith, 23 October 1991 and 8 August 1992, 10.D.10, John Beckwith papers, Faculty of Music Library, University of Toronto; Elliott and Smith 2001, 9on34; Beckwith $2011,31$. 
Beckwith, John, 2011. "Istvan Anhalt: A Character Sketch." In Centre and Periphery, Roots and Exile, ed. Friedemann Sallis, Robin Elliott, and Kenneth DeLong, 29-35. Waterloo, ON: Wilfrid Laurier University Press.

Bird, Kai, and Martin J. Sherwin. 2005. American Prometheus: The Triumph and Tragedy of J. Robert Oppenheimer. New York: Vintage Books.

Chiasson-Taylor, Rachel. 2011. "Le Fonds Istvan Anhalt (MUS 164) à Bibliothèque et Archives Canada." In Centre and Periphery, Roots and Exile, ed. Friedemann Sallis, Robin Elliott, and Kenneth DeLong, 199-215. Waterloo, ON: Wilfrid Laurier University Press.

Elliott, Robin, and Gordon E. Smith, eds. 2001. Istvan Anhalt: Pathways and Memory. Montreal and Kingston: McGill-Queen's University Press.

Gillmor, Alan, ed., 2007. Eagle Minds: Selected Correspondence of Istvan Anhalt and George Rochberg. Waterloo, ON: Wilfrid Laurier University Press.

Laki, Peter. 2009. “Two Operatic Oppenheimers.” Unpublished.

Murrell, John. 1990. "Oppenheimer and the Others" (preliminary structural outline), file 6.5, John Murrell Fonds, University of Calgary Library, Calgary.

Smith, Gordon E. 2006. "From New France to a 'Millennial Mall': Identity Paradigms in Istvan Anhalt's Operas." American Music 24 (2): 172-93.

Straus, Joseph N. 2008. "A Revisionist History of Twelve-Tone Serialism in American Music." Journal of the Society for American Music 2 (3): 208-09.

\section{ABSTRACT}

The "opera fantasy" Oppenheimer by Istvan Anhalt (1919-2012) survives as a draft libretto and 1,10o pages of musical sketches, on which the composer concentrated from mid-1988 to late 1991, partly with the collaboration of the playwright John Murrell. Prolonged negotiations with the Canadian Opera Company eventually collapsed and the work was abandoned. Using prior research by Peter Laki and archival documents (especially the composer's previously inaccessible "diary" of the opera's progress), this article traces Oppenheimer's compositional development and the COC production talks, compares it to the 2005 opera Doctor Atomic by John Adams and Peter Sellars (both works deal with J. Robert Oppenheimer's role in creating the first atomic bomb), and speculates on possible affinities between the existing sketches and other Anhalt compositions of the same period.

\section{RÉSUMÉ}

Une version de travail du livret d'opéra pour l'opéra-fantasie Oppenheimer d'Istvan Anhalt (1919-2012) est conservée ainsi que 1100 pages d'esquisses musicales (Bibliothèque et Archives Canada, Fonds Anhalt, MUS 164). Le compositeur a travaillé principalement sur cette œuvre de mi-1987 à fin 1991, parfois avec la collaboration du dramaturge John Murrell. De longues négociations avec la Canadian Opera Company ont finalement mené à un échec et le projet a été abandonné. Sur la base des recherches de Peter Laki et des documents d'archives (en particulier le journal de projet du compositeur, jusqu'à maintenant inaccessible), cet article retrace le développement 
compositionnel d'Oppenheimer ainsi que les négociations avec la COC, en comparaison avec l'opéra de John Adams et Peter Sellars, Doctor Atomic (2005), les deux opéras traitant du rôle du physicien J. Robert Oppenheimer dans le développement de la bombe atomique en 1945. L'examen des esquisses amène également à considérer les affinités entre elles et avec d'autres œuvres d'Anhalt de la même période. 